\title{
A retórica da reeleição: mapeando os discursos dos Programas Eleitorais (HGPE) em 1998 e 2006
}

\author{
\begin{tabular}{c}
\hline Mônica Machado \\
Programa de Doutorado em Comunicação \\
Escola de Comunicação \\
Universidade Federal do Rio de Janeiro \\
\hline \hline
\end{tabular}
}

Resumo: 0 artigo avalia a produção dos discursos do HGPE na TV dos partidos de dois candidatos à reeleição para a Presidência da República: Fernando Henrique (PSDB) em 1998 e Luiz Inácio Lula da Silva (PT) em 2006. É objeto de reflexão indagar até que ponto as campanhas orientadas para reconduzir o mandatário ao poder têm estruturas estratégicas discursivas similares nos dois contextos, apesar de inscrições partidárias e orientações políticas distintas. Como metodologia, utiliza procedimentos para entender os elementos retóricos de cada campanha e apreender as estratégias de persuasão. Nota-se que o estímulo ao voto retrospectivo, o discurso a favor da continuidade da gestão administrativa, o lugar de autoridade do candidato-Presidente e a ênfase em discurso programático de cunho econômico são enunciados proferidos pelos mandatários nos dois contextos. É lícito supor, então, que a retórica da reeleição favorece posições privilegiadas na disputa.

Palavras-chave: propaganda eleitoral; reeleição presidencial; retórica política

\begin{abstract}
The article evaluates the production of the speeches of electoral advertising in TV of the two presidential candidates: Fernando Henrique (PSDB) in 1998 and Luis Inácio Lula of Silva (PT) in 2006. Therefore, the point is to investigate to what extent the campaigns show discursive strategic structures . similar in the two contexts - in spite of supporting registrations and different political orientations. The methodology uses procedures to understand the rhetorical elements of each campaign and persuasion strategies. In both campaigns one observes the incentive to the retrospective vote, the speech in favor of the continuity of the administration, the place of the candidate-president's authority, the emphasis in speech of economical issues. One can suggest that the rhetoric of the reelection favors positions in the electoral dispute.
\end{abstract}

Keywords: electoral advertising; presidential reelection; political rethoric 


\section{Introdução}

$\mathrm{Na}$ literatura contemporânea da ciência política, nota-se relativo interesse por efeitos de campanha eleitoral e seus impactos no comportamento do cidadão. Holbrook afirma que "os eleitores são, claro, motivados por outros fatores como identificação partidária, ideologia, raça, religião e suas posições frente aos fatos, mas a informação que recebem durante a campanha pode afetar o peso que eles dão a esses fatores "(HOLBROOK, 1996, p.59). Popkin (1994) também reflete sobre o papel dos meios de informação para a tomada de decisão do eleitorado. Salienta o conceito de "atalho cognitivo"como uma categoria relevante para se pensar a influência dos meios de comunicação no processo eleitoral. Dirá que em um contexto de forte pressão, como é o período do sufrágio universal, o eleitor buscará atalhos para justificar sua posição, e que esses mecanismos cognitivos são, muitas vezes, impactados pela informação que recebem ao longo da campanha. O espaço da campanha é, na perspectiva do autor, o locus de disputa da interpretação do mundo, e desse modo, apresenta-se como mais uma variável no processamento de escolha eleitoral.

A hipótese deste trabalho é que o Horário Gratuito de Propaganda Eleitoral (HPGE) oferece enquadramentos narrativos que auxiliam o eleitorado na tomada de decisão. As informações veiculadas através do HGPE e dos spots, tanto em rádio como em televisão, concorrem com outros acionamentos midiáticos na disputa pela atenção do eleitor - como as matérias veiculadas nos telejornais; nos jornais impressos; os debates; os programas de entrevistas - e são processadas pelo eleitor que, como diz Holbrook (1996), já tem predisposições baseadas em variáveis ideológicas, identidade partidária ou outros condicionantes, e sofrem também a influência da campanha.

Embora em estudo apresentado por Figueiredo $(2000)^{1}$ medindo a importância das fontes de informação para a decisão de voto, o horário eleitoral na TV e no rádio se apresenta como última variável em importância para tomada de decisão (apenas $22 \%$ dos eleitores consideraram a fonte muito importante), ficando atrás de noticiário de TV, rádio e jornais (53\%); das conversas com amigos, familiares e colegas (52\%); dos $38 \%$ que falam dos resultados de pesquisa de opinião e dos $32 \%$ que preferem a orientação de sindicatos, igrejas e outras associações - entendemos que a ação do HGPE não se dá através de uma relação de causa e efeito; o papel da propaganda eleitoral está em construir um cenário de representação do mundo atual e futuro, mapear indícios de imagem dos candidatos e seus partidos ao longo da corrida eleitoral. É, portanto, esse olhar sobre a

\footnotetext{
1 Figueiredo (2000) apresenta tabela de Pesquisa Datafolha, março de 1994, cidade de São Paulo, estudo quantitativo, 1.080 casos (apud VENTURI, 2005).
} 
MACHADO, M. A retórica da reeleição: mapeando os discursos dos...

influência da propaganda eleitoral que vamos imprimir ao estudo da narrativa discursiva dos programas na TV.

O recorte da análise aqui empreendida está centrado na produção discursiva dos filmes do HGPE na televisão em dois contextos, quais sejam, as eleições majoritárias para a presidência da República em 1998 e 2006. Em 1998, o Brasil viveu sua terceira eleição direta presidencial após a redemocratização, a primeira em que o presidente concorreu à reeleição no período. Em 2006, tivemos a quinta eleição para a Presidência do período, também com a possibilidade de reeleição. Fernando Henrique Cardoso foi reconduzido ao cargo para um novo mandato em 1998 com quase 36 milhões de votos válidos ou 53,06\% do eleitorado, em $1^{\circ}$ turno, segundo os dados do TSE². Por sua vez, Luiz Inácio Lula da Silva em 2006, de acordo com a mesma fonte, foi reeleito com mais de 46 milhões de votos válidos, ou por $46 \%$ dos eleitores em $2^{\circ}$ turno.

Os pressupostos conceituais para análise estão baseados na tradição de pensar as narrativas da comunicação política como arenas de representação. Tais noções estão em debate desde a Retórica de Aristóteles e se replicam nas teses sobre a arte poética no mundo da cultura política (GOMES, 2004; GEERTZ, 1980): o uso de representações nas lógicas de encenação - do drama às ações de natureza emocional - e da retórica - no sentido do uso das linguagens argumentativas para efeito de persuasão. Seguindo essa tradição para análise dos discursos veiculados na propaganda eleitoral, os percursos metodológicos utilizados neste estudo comparativo serão os mesmos adotados por Veiga (2001) em sua tese de doutorado ao mapear as narrativas dos programas do horário eleitoral dos três candidatos de maior destaque na eleição presidencial de 1998. As proposições de sua pesquisa eram entender a construção discursiva de cada campanha; apreender as estratégias de persuasão e verificar a apropriação e o uso dos discursos dos candidatos no processamento das razões de voto do eleitorado. As categorias de análise utilizadas foram baseadas nos esquemas conceituais desenvolvidos por Albuquerque (1996, 1999) e Figueiredo et al (2000) e serão novamente adotadas para análise dos programas de 2006 para o estabelecimento de parâmetros comparativos.

Veiga (2001) traz da análise de Albuquerque os esquemas conceituais para compreensão dos discursos da propaganda eleitoral que separam os conteúdos dos programas em segmentos de campanha, auxiliares e meta-campanha. Albuquerque define como unidades temáticas de campanha os discursos retrospectivos e propositivos, as plataformas eleitorais, as cenas de apresentação do candidato e do partido, compromissos com o futuro. Os segmentos auxiliares seriam os recursos de linguagem que oferecem suporte conotativo às mensagens: jingle, estruturas de videoclipe, vinhetas. E os recursos de meta-campanha, como a própria expressão

2 Disponível em: < www.tse.gov.br>. Acesso em: 10 fev. 2007. 
revela, referem-se a quando a campanha fala sobre si própria. Nesse caso, teríamos a exploração do uso de pesquisas eleitorais salientando a posição do candidato/ partido no ranking, as cenas de comícios, a mobilização da campanha nas ruas.

Associando o quadro metodológico de Albuquerque ao mapeamento de Figueiredo et al (2000), Veiga cria condições de análise das estratégias de persuasão utilizadas nas campanhas majoritárias. A hipótese central de sua tese é que, no contexto eleitoral, os atores políticos criam um cenário de representação onde a argumentação sobre o mundo atende aos objetivos de persuadir o eleitorado. Por isso, candidatos e partidos, dependendo de sua posição na disputa, constroem uma imagem sobre o mundo atual e projetam perspectivas sobre o mundo futuro. Como salienta Veiga, mostrou-se necessário ajustar a metodologia para análise do HPGE, já que o estudo proposto por Figueiredo et al foi aplicado para análise dos spots nas campanhas para Prefeitura de São Paulo e Rio de Janeiro em 1996. Deste modo, trabalhando com as mesmas variáveis da análise dos programas do Horário Eleitoral em 1998, para estudar os discursos veiculados no HGPE em 2006, utilizamos as categorias de formato do programa proposta por Albuquerque e a análise das estratégias de comunicação de campanhas, a construção do discurso, os objetivos das mensagens, as características pessoais dos candidatos e os temas levantados da campanha da abordagem de Figueiredo et al.

\section{Breve contextualização das disputas eleitorais para Presidência da República em 1998 e 2006}

A eleição presidencial de 1998 , decidida no $1^{\circ}$ turno, foi disputada por doze candidatos: Fernando Henrique Cardoso (PSDB, PFL, PTB); Luiz Inácio Lula da Silva $(P T)$, Ciro Gomes (PPS); Enéas Carneiro (PRONA); Ivan Frota (PMN); Alfredo Sirkis (PV); Zé Maria (PSTU); João de Deus (PT do B); Eymael (PSDC); Thereza Ruiz (PTN), Sérgio Bueno (PSC) e Vasco Neto (PSN).

Por sua vez, houve em 2006 um enxugamento de partidos políticos na disputa para apenas oito candidaturas: Luiz Inácio Lula da Silva (PT, PL); Geraldo Alckmin (PSDB; PFL); Cristovam Buarque (PDT); José Maria Eymael (PSDC); Luciano Bivar (PSL); Heloísa Helena (PSOL, PSTU); Ana Maria Rangel (PRP); Rui Costa Pimenta (PCO).

Segundo dados do IBOPE ${ }^{3}$, os mandatários nas disputas (os candidatos à reeleição) mantiveram-se nas lideranças das intenções de voto durante toda a corrida dos processos eleitorais de 1998 e 2006, o que sugere inúmeros questionamentos em relação às estratégias por eles utilizadas para convencer o

\footnotetext{
${ }^{3}$ Série histórica de intenção de voto para Presidência da República em 1998 e 2006. Disponível em: < www.ibope.com.br> Acesso em: 30. nov. 2006
} 
eleitorado da pertinência da reeleição tais como: o uso da máquina administrativa ou de estratégias da ameaça frente à perspectiva de mudança.

De acordo com Veiga, a estratégia predominante da campanha de Fernando Henrique Cardoso em 1998 estava centrada na defesa da continuidade do modelo econômico vigente, o Plano Real e, portanto, ressaltava que o melhor mundo futuro seria construído por seu partido. Como diz a autora: "a estratégia da competência foi adotada por Fernando Henrique que aparecia como um grande estadista, possuidor de uma capacidade singular de gerenciar os problemas da nação" (VEIGA, 2001, p.68). Em 2006, observou-se como estratégia dominante da campanha de Lula a defesa da continuidade do modelo de crescimento econômico, viabilizando, simultaneamente, desenvolvimento na área social. A retórica prevalecente foi argumentar que, durante sua gestão, o Brasil passou a associar avanços na economia com transferência de renda para as classes populares. Diferente de FHC, Lula equilibrou a estratégia da competência como mandatário com a estratégia da identificação com as classes populares. Como veremos adiante, inúmeros dispositivos de sedução foram acionados para reforçar o seu vínculo de proximidade com a população.

Observa-se, portanto, o uso de estratégias similares que oferecem garantias para o eleitorado: os bons indicadores da área econômica da gestão anterior. A estratégia de persuasão está baseada na mobilização do que Fiorina (1981) define como voto retrospectivo ${ }^{4}$.

Apesar de o foco deste artigo ser a análise dos discursos da propaganda eleitoral, vale um breve relato sobre a participação da mídia informativa na construção de uma agenda temática que fornece registros cognitivos para escolha racional do voto do eleitorado. Como diz Miguel (2002), os programas do horário eleitoral tendem a se apresentar como contra-pautas às agendas dos veículos de informação, concorrendo pela atenção do eleitorado ao oferecer leituras diversas sobre o mundo atual. Em 1998, ao analisar a participação do Jornal Nacional da Rede Globo na construção da hipótese do agenda-setting ${ }^{5}$ das eleições presidenciais, Miguel salienta a invisibilidade do processo eleitoral na cobertura noticiosa do telejornal. As pautas apresentadas pelos candidatos oposicionistas, como o desemprego e a seca no nordeste, foram eliminados da agenda do Jornal Nacional após a Copa do Mundo em julho de 1998. Até mesmo o tema que ganhou relevância

\footnotetext{
4 Em sua concepção, o eleitor vota levando em consideração o julgamento da trajetória administrativa dos governantes; nesse sentido, o custo da decisão eleitoral se abrevia. Ou ainda, o eleitor passa a orientar a direção do seu voto em função da avaliação positiva ou negativa de governos anteriores. Não é relevante aqui os discursos de futuras promessas e sim a retórica comprobatória de realizações do passado.

${ }^{5}$ Conceito utilizado na teoria do jornalismo que objetiva entender a correlação de forças entre as agendas midiáticas, agendas públicas e políticas governamentais na construção da agenda temática das editorias jornalísticas (TRAQUINA, 2000).
} 
central na disputa eleitoral daquele ano, a crise econômica internacional, recebeu enquadramento peculiar no Jornal Nacional. Segundo Miguel, o telejornal demorou em noticiar um quadro de crise, centrou ênfase no caráter externo do problema e conduziu suas matérias no intuito de revelar a competência da equipe econômica do governo brasileiro para enfrentar a crise. E ainda, não deu visibilidade às leituras propostas pelos partidos oposicionistas: os argumentos da fragilidade e vulnerabilidade da política econômica brasileira frente à crise internacional. Em matéria veiculada no site do Observatório da Imprensa, Gentilli (1998) afirma: "Daqui a 30 anos, quando os historiadores forem estudar a campanha presidencial de 1998, os jornais e telejornais vão se evidenciar como muito pouco úteis para a compreensão do que efetivamente ocorreu neste segundo semestre de 1998"6. Em sua perspectiva, o silêncio programático dominou hegemonicamente as editorias de política na imprensa escrita no ano de 1998. O enquadramento noticioso da eleição limitou-se à cobertura do fatual, ou seja, com foco no acompanhamento da agenda diária de campanha dos candidatos, evitando uma linha investigativa mais consistente dos temas que gravitavam em torno das eleições daquele ano.

Há diferenças substantivas quando se analisa a participação da mídia noticiosa na cobertura do processo eleitoral de 2006. Segundo pesquisa do Doxa ${ }^{7}$, que estuda a participação da mídia na cobertura dos candidatos na eleição de 2006, a avaliação de valência de Lula como candidato e Lula presidente nos quatros jornais de maior expressão no eixo Rio - São Paulo - O Globo, JB, o Estado de São Paulo e Folha de São Paulo - revela tendência majoritária de valência negativa para imagem do candidato do PT. Estabelecendo uma correlação entre o início do horário eleitoral na TV (15/08) e o estudo de valência no jornal O Globo, observa-se que a valência negativa de Lula no veículo esteve em queda (redução de seis pontos percentuais, passando de $47 \%$ para $41 \%$ de $1 / 08$ a 15/08). No entanto, no período da crise do Dossiê, já no desfecho do $1^{\circ}$ turno (13/09 à 01/10), a valência negativa de Lula no jornal subiu para $58 \%$. Neste mesmo período, a valência negativa de Lula era de $60 \%$ em o Estado de São Paulo, $45 \%$ na Folha de São Paulo e 43\% no Jornal do Brasil.

Essas análises mostram que, se o silêncio da mídia informativa privilegiou o candidato à reeleição em 1998, pois Fernando Henrique Cardoso pôde em seu programa eleitoral defender a imagem de sua política econômica sem que a imprensa provocasse contrapontos ou análises das condições adversas, o mesmo não ocorreu com o candidato à reeleição pelo PT em 2006. Nessa eleição, a campanha situacionista contou quase exclusivamente com o espaço da propaganda

\footnotetext{
6 "A eleição sem reportagem". Disponível em: < observatório. ultimo segundo.ig.com.br>. Acesso em: 15 jan. 2007.

7 Dados da cobertura jornalística das eleições presidenciais. Disponível em:< www.doxa.iuperj.br>>. Acesso em: 20 fev. 2007.
} 
MACHADO, M. A retórica da reeleição: mapeando os discursos dos...

do horário eleitoral para a defesa de suas proposições. A agenda negativa do governo do PT ganhou destaque na maior parte das editorias jornalísticas das mídias impressa e eletrônica: a retomada do debate sobre a crise ética na política, os escândalos de corrupção envolvendo lideranças do PT, os indicadores econômicos que revelavam desaceleração do crescimento, a elevação nas taxas de juros e a carga tributária em alta.

Esse clima de opinião apresentado pela mídia informativa em 2006 favoreceu os candidatos oposicionistas, especialmente a candidatura de Geraldo Alckmin que, como veremos à frente, aproveitou-se da aura de credibilidade dos jornais para utilizá-los em profusão no seu programa eleitoral para ratificar as críticas ao PT e a Lula.

Em 2006, segundo legislação do $\mathrm{TSE}^{8}$, foi proibida a realização de showmícios, uso de propaganda promocional dos partidos (bonés, camisetas, brindes), bem como campanhas no espaço público: foi vetado o uso de mídia exterior (outdoor, busdoor, galhardetes etc). Nesse sentido, é possível sugerir que a propaganda eleitoral na televisão ocupou um papel mais importante como esfera de visibilidade da campanha, na medida em que outros recursos não puderam ser disponibilizados para aquecer a disputa.

Os debates, por sua vez, esquentaram a dinâmica do processo eleitoral no primeiro turno em 2006, mas sem a presença do candidato à reeleição, Luiz Inácio Lula da Silva: ocorreram três debates, a saber, em 14/08 na TV Bandeirantes, em 13/09 na TV Gazeta e, na véspera do $1^{\circ}$ turno, em 29/09 na TV Globo. No $2^{\circ}$ turno, Lula participou de todos os debates, ocorridos em 8/10 na TV Bandeirantes, em 19/10 no SBT, em 23/10 na TV Record e em 27/10 na TV Globo.

\section{Análise dos efeitos da propaganda eleitoral gratuita das campanhas presidenciais de 1998 e 2006}

Antes de entrarmos na análise específica dos discursos dos programas eleitorais vale pensarmos a respeito dos efeitos da campanha eleitoral sobre a opinião pública com referência à hipótese de Holbrook. Interessante observar que, segundo o autor:

\footnotetext{
"Uma das dificuldades de estudar os efeitos da campanha em seu nível individual, é que a maioria dos surveys não é projetada para estudar tais efeitos. Parte da razão para isto é que são mapeados estudos centrados em premissas sobre modelos dominantes de
}

8 Disponível em: < www.tse.gov.br>. Acesso em: 20 dez. 2006. 
comportamento eleitoral que não enfatizam os efeitos de campanha" (HOLBROOK, 1996, p.51 ).

Sua tese é que, se os efeitos fossem nulos, esperaríamos uma constância no comportamento do eleitorado e que, no entanto, há situações de oscilações relevantes ao longo da campanha, ressaltando a importância de um olhar mais atento para a influência dos eventos de campanha como elementos auxiliares nos atalhos cognitivos utilizados pelo eleitorado para dirigir o voto. De acordo com Veiga (2001), na campanha eleitoral de 1998, não houve alterações significativas nas intenções de voto do eleitorado após o início do horário eleitoral. Mas, observando os dados da série histórica do Instituto Datafolha ${ }^{9}$, verifica-se que no dia 14 de agosto de 1998, Fernando Henrique Cardoso tinha 44\% das intenções de voto, contra $21 \%$ dos votos em Lula; em 2 de setembro, FHC chegou a $49 \%$ das intenções de voto e Lula a $26 \%$. O candidato à reeleição cresceu quatro pontos percentuais nos primeiros vinte dias da campanha eleitoral e sustentou a diferença ao longo da disputa. Pode-se trabalhar com a hipótese de que a estratégia de mandatário de Fernando Henrique Cardoso revelando um bom mundo atual com controle da inflação e estabilidade econômica na propaganda eleitoral mobilizou a opinião pública e contribuiu para a direção do voto. Nem mesmo o fato exógeno da crise econômica internacional alterou a constância das intenções de voto da opinião pública em relação a $\mathrm{FHC}$.

Em 2006, como a campanha teve mais ritmo, uma profusão de debates, uma ação mais direta da mídia informativa no processo eleitoral e ações discursivas de impacto na propaganda eleitoral gratuita, verificamos maior alteração na evolução da intenção de voto da população, quando observados a partir das datas dos eventos de campanha. É o que mostra o Gráfico 1 , referente à disputa no $1^{\circ}$ turno:

${ }_{9}$ Disponível em: < www.datafloha. folha. uol. com.br >. Acesso em: 20 jan. 2007. 


\section{Gráfico1}

Evolução das intenções de voto para os candidatos à eleição Presidencial de 2006 ( $1^{\circ}$ turno) e registros dos eventos de campanha

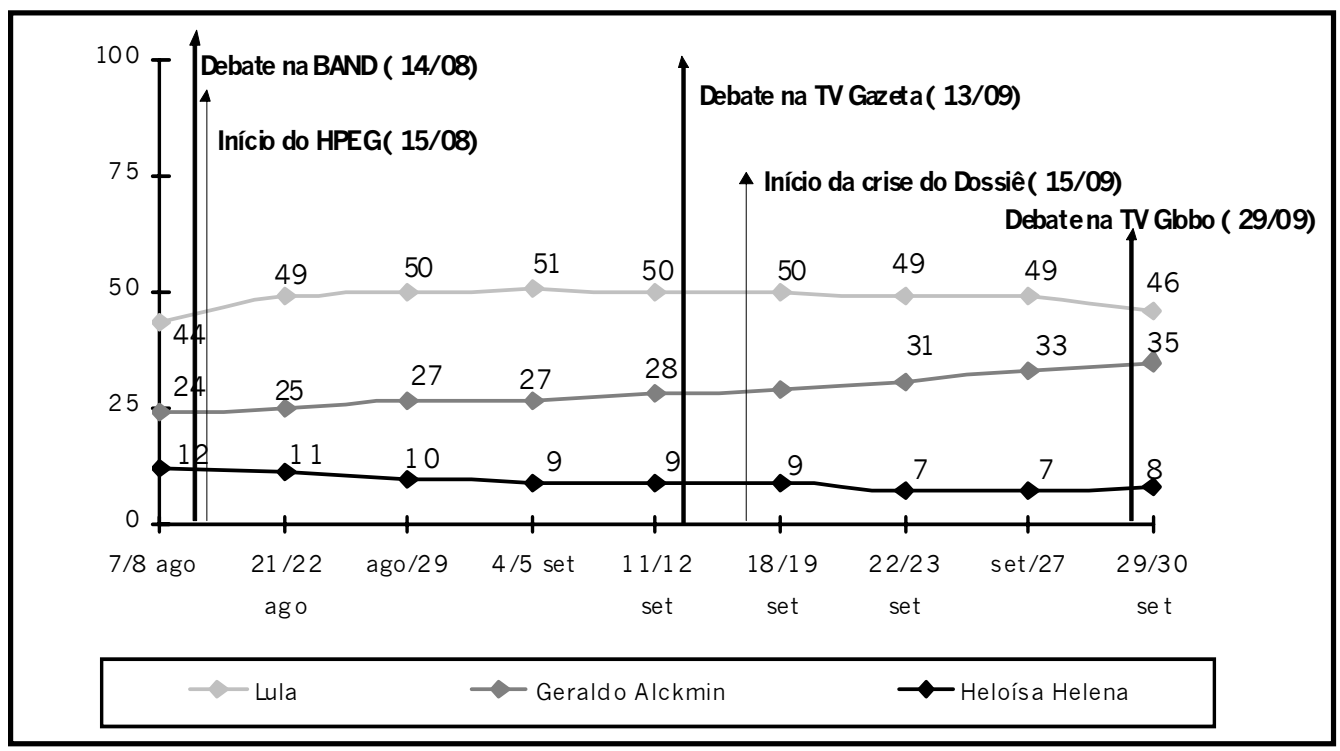

Fonte: Instituto Datafolha, 2006

Nota-se que no início da propaganda eleitoral, Lula cresceu quatro pontos percentuais, assim como Fernando Henrique em 1998. A estratégia de mandatário adotada por Lula esteve centrada em revelar os bons indicadores de desempenho econômico e sociais da sua gestão. Outro recurso foi utilizado como fator de mobilização: a estratégia de identificação. A retórica da sedução foi acionada nos segmentos auxiliares da campanha do candidato à reeleição: a vinheta de abertura do programa reforçou essa tendência, com imagens superpostas de Lula em diversos cenários em interação com o povo. A linguagem do programa, com tom fortemente emocional buscou capturar a atenção do espectador pela linguagem da sedução. O refrão do jingle "É Lula de novo com a força do povo" objetivou aproximar o líder carismático de seus eleitores, com a proposição dominante de estabelecer vínculo de identidade de Lula com as classes populares.

Após o crescimento das intenções de voto nas duas primeiras semanas de campanha observou-se certa constância no quadro de intenções de voto em Lula até o início da crise do Dossiê dos Vedoin ${ }^{10}$. Em 27 de setembro, quando a agenda dos

10 Dossiê com documentos que visavam envolver os candidatos do PSDB Alckimin e Serra no escândalo de liberação de ambulâncias, esquema associado à "máfia das sanguessugas" chefiadas por Luis Antonio Vedoin. 
candidatos oposicionistas, especialmente Geraldo Alckmin, do PSDB, e Heloísa Helena, do PSOL, concentraram seus programas nas críticas em relação aos escândalos de corrupção envolvendo o PT, a mídia noticiosa intensificou a cobertura do escândalo, procurando apurar todos os detalhes da trama. Lula perdeu três pontos percentuais e manteve sua queda na corrida eleitoral após a ausência no debate da Rede Globo no dia 29 de setembro. Segundo o TSE, Lula chegou às eleições do $1^{\circ}$ turno com $48,61 \%$ dos votos válidos do eleitorado, não atingindo o mínimo necessário - 50\% mais um - para não levar a disputa para o segundo turno.

O candidato oposicionista de maior expressão na disputa, Geraldo Alckmin, cresceu progressivamente ao longo da campanha, após o início da propaganda eleitoral. O programa do PSDB iniciou no dia 15 de agosto de 2006 com o objetivo de torná-lo conhecido da população brasileira. Após a escolha de seu nome pela bancada do partido para concorrer à eleição presidencial de 2006, era preciso ampliar sua imagem para fora do território paulistano e, por isso, a campanha concedeu nos primeiros programas bom espaço para a trajetória biográfica de Alckmin:

Loc V - "Com 53 anos, o paulista Geraldo Alckmin foi vereador aos 19 anos, Prefeito aos 23, três vezes deputado, vice de Mário Covas e governador de São Paulo por seis anos. Médico, casado, com três filhos e uma neta. Geraldo é um homem de bem para o bem do Brasil”.

O posicionamento adotado por Alckmin na campanha foi o de desafiante. $\mathrm{Na}$ tentativa de mapear um discurso de oposição, o candidato do PSDB marcou posição como o candidato da ética, da decência, do trabalho honesto. Sem explicitar, tentou fazer contraponto com a imagem maculada do PT com sucessivos escândalos de corrupção.

No período da crise do Dossiê, denúncias desencadeadas pela compra pelo PT de informações que comprometeriam a candidatura de José Serra em São Paulo, Geraldo Alckmin aproveitou a oportunidade para resgatar todo o histórico de envolvimento das lideranças do partido em escândalos de corrupção. Como a imprensa utilizou-se muito da pauta do Dossiê, Alckmin recorreu inúmeras vezes às chamadas dos jornais impressos e às imagens dos programas de telejornalismo para conferir credibilidade à suas acusações. Nesse período, sua candidatura cresceu seis pontos percentuais.

Alckmin chegou ao fim do $1^{\circ}$ turno com $41,64 \%$ dos votos válidos. Como podemos verificar no Gráfico 1 o Instituto Datafolha apontava 35\% das intenções de 
voto para Alckmin na véspera do sufrágio, seis pontos percentuais a menos do que o resultado das urnas.

A campanha do $2^{\circ}$ turno iniciou com Lula em vantagem em termos de apoios políticos. Uma jogada errada de Geraldo Alckmin ao pedir o apoio de Antony Garotinho criou para o candidato do PSDB uma predisposição negativa da imprensa carioca frente ao episódio.

Gráfico 2

Evolução das intenções de voto para os candidatos à eleição Presidencial de 2006 ( $2^{\circ}$ turno) e registros dos eventos de campanha

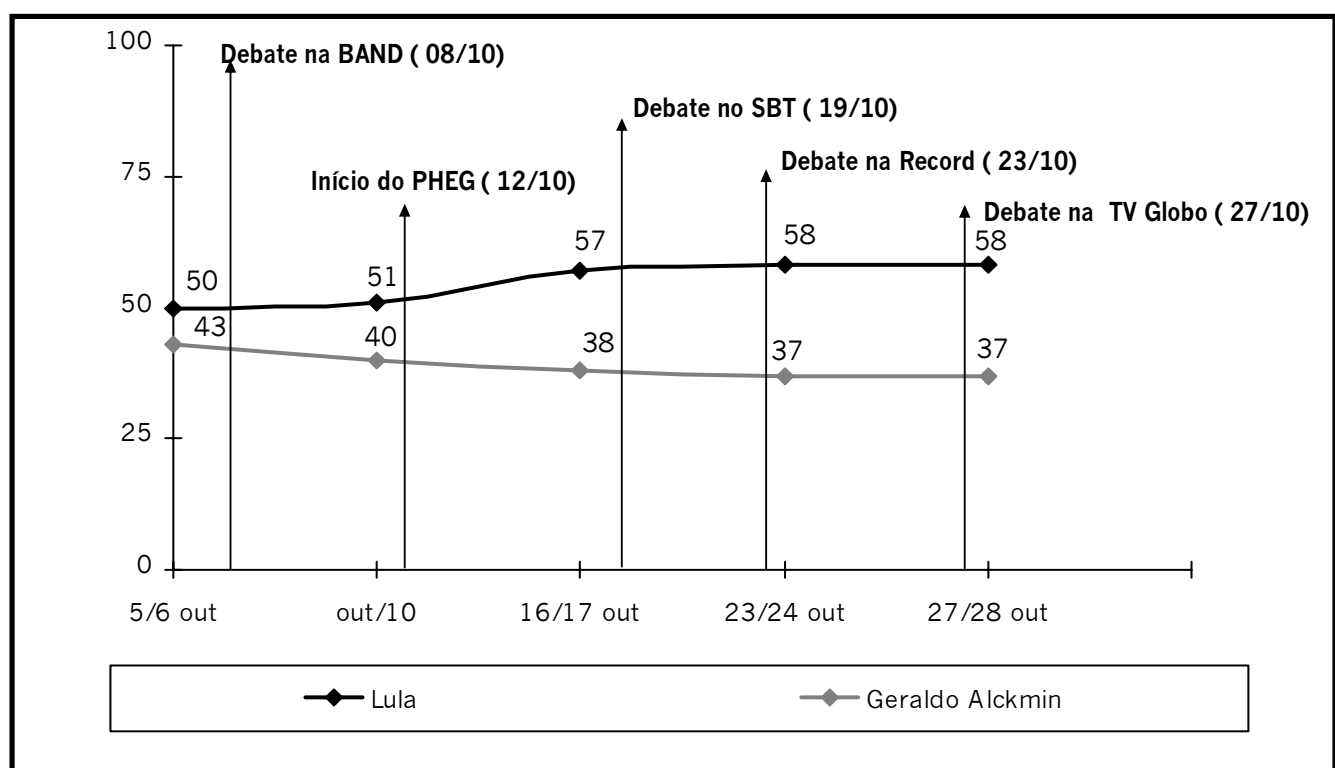

Fonte: Instituto DataFolha, 2006

Lula levou muito tempo para realizar o discurso propositivo e só optou por equilibrar a distribuição do programa eleitoral em "prestação de contas" e propostas para a nova gestão no $2^{\circ}$ turno. Mesmo assim, a distribuição de tempo foi mais representativa para realizações, dedicando-se muito mais a falar de sua gestão no plano econômico, em infraestrutura, na saúde e educação. Mas, dessa vez, o discurso ganhou reforço de legitimidade dos dados da PNAD-IBGE. Outro interlocutor é, portanto, acionado para ratificar o discurso do "bom governo".

No $2^{\circ}$ turno, frente à posição mais agressiva do PT de comparar as realizações do governo do PSDB e do PT em relação aos indicadores econômicos, políticas sociais e projetos de privatização, Alckmin optou por sustentar o discurso do $1^{\circ}$ turno e não entram diretamente em confronto. Não respondeu na propaganda eleitoral às críticas ao programa de privatizações e não argumentou sobre o 
investimento na área social no governo FHC. Seguiu reforçando os valores de ética, honestidade, compromisso com trabalho sério. O candidato do PSDB saiu das urnas com 39,17\% dos votos do eleitorado, em termos absolutos, mais de 37 milhões de votos. Curiosamente, o candidato obteve menos votos no $2^{\circ}$ turno do que obteve no $1^{\circ}$, quando chegou à marca de quase 40 milhões de votos.

Em contraposição, na campanha de Lula, os segmentos auxiliares foram acionados em profusão com intuito de aproximar o líder benevolente de seus eleitores. O último programa recorreu à gramática poética como forma de sedução; o recurso de sensibilização musical foi acionado: a $9^{\circ}$ Sinfonia de Beethoven como pano de fundo. $O$ discurso de oportunidade foi revelado, pois Lula fez aniversário no dia da eleição do $2^{\circ}$ turno. O programa aproveitou e explorou o fato, através da apresentação de crianças caminhando por um cenário idílico, levando um bolo para Lula. Toda encenação teve por objetivo ampliar a vantagem eleitoral do candidato. Um projeto bem sucedido: Lula saiu das urnas com $60,83 \%$ dos votos, com a adesão de mais de 58 milhões de eleitores em termos absolutos.

\section{Análise das estratégias discursivas dos textos do HGPE em 1998 e 2006}

Para analisar os programas comparativamente em 1998 e 2006, optamos por um mapeamento de enquadramentos dominantes dos discursos na cena televisiva dos candidatos de maior visibilidade nas disputas. Em 1998, como a eleição foi definida no $1^{\circ}$ turno, temos 20 programas de Fernando Henrique (PSDB), Luiz Inácio Lula da Silva (PT) e Ciro Gomes (PPS). Em 2006, no $1^{\circ}$ e $2^{\circ}$ turnos foram 20 programas dos três candidatos com maior visibilidade na disputa: Luiz Inácio Lula da Silva (PT), Geraldo Alckmin (PSDB) e Heloísa Helena (PSOL), e 16 programas no $2^{\circ}$ turno entre Lula e Alckmin.

De acordo com Veiga (2001), a campanha na TV em 1998 pode ser dividida em dois momentos: o primeiro, quando candidatos situacionistas e oposicionistas travaram diálogo sobre os desdobramentos do Plano Real e no segundo, após a crise econômica internacional, quando a campanha concentrou-se nos impactos sobre a sociedade brasileira. A oposição defendeu o argumento da vulnerabilidade da política econômica nacional e a situação argumentou sobre a preparação do Brasil para enfrentar a crise, discursou em defesa da moeda forte e salientou o perfil de seu governo sério e competente.

Em contraposição, a campanha de 2006 viveu três marcos significativos: um primeiro momento em que a campanha não foi dialógica, em que cada candidato teve a intenção de marcar sua posição de imagem para o eleitorado: Lula adotou estratégia de mandatário, reforçando o argumento do melhor mundo atual, revelando suas realizações nos últimos quatro anos de governo, com ênfase na associação entre crescimento econômico e transferência de renda; Alckmin 
MACHADO, M. A retórica da reeleição: mapeando os discursos dos...

pretendeu ser conhecido da população e enfatizou o discurso biográfico administrativo e político; e Heloísa Helena apresentou-se como desafiante sugerindo ser a alternativa da ética e justiça social. Na segunda fase, após a crise do Dossiê, Lula adotou a estratégia da ameaça com o slogan "Não troque o certo pelo duvidoso. Eu quero Lula de novo", lançando mão dos mecanismos de poder que a reeleição Ihe confere. Geraldo Alckmin optou por ação mais incisiva e apropriou-se de estratégias de desafiante em evidência: explorou ao máximo em seu programa elementos da crise moral que se abateu sobre o PT, retomou imagens de lideranças partidárias envolvidas em escândalo de corrupção e ressaltou a crise do Dossiê dos Vedoin como mais um esquema de corrupção no governo. Também utilizou de inúmeras matérias do $O$ Globo e $O$ Estado de São Paulo em seu programa para ratificar as falas sobre a crise, e equilibrou o seu programa entre o discurso crítico ao oponente e o discurso centrado na lógica da distinção, com ênfase em valores, como revela o jingle de sua campanha: "Por um Brasil honesto e competente, Geraldo Presidente". Com o tempo muito reduzido na campanha, Heloísa Helena não conseguiu desenvolver o discurso propositivo e elevou o tom crítico contra os esquemas de corrupção no governo do PT.

No terceiro e último momento da campanha, já no $2^{\circ}$ turno, frente à posição mais agressiva do PT de comparar as realizações do governo do PSDB e do PT em relação aos indicadores econômicos, políticas sociais e projetos de privatização, Alckmin optou por reforçar os valores de ética, honestidade, compromisso com trabalho sério. Lula, por sua vez, reforçou a estratégia da ameaça, intensificando o uso do conceito "Não troque o certo pelo duvidoso" e enfatizando a estratégia da identificação, com foco na apologia ao candidato e seus vínculos com o povo. Tal como salienta a estratégia da identificação, ampliou os recursos de sedução centrados na persona, traduzida na liderança carismática fortemente identificada com as classes populares, e pelo slogan "Deixa o homem trabalhar!".

\section{Análise comparativa dos discursos dos candidatos à reeleição: Fernando Henrique Cardoso (1998) e Luiz Inácio Lula da Silva (2006).}

Verificam-se inúmeros pontos de convergência entre as estratégias dos mandatários nas campanhas presidenciais de 1998 e 2006. Nos discursos dos candidatos à reeleição prevalecem as traduções positivas do mundo atual. Enquanto Fernando Henrique buscava ativar a lembrança do eleitorado de que em seu governo a inflação foi controlada, promoveu a estabilidade econômica e assegurou o sucesso do Plano Real, Lula buscou salientar os indicadores de crescimento econômico relacionados ao desenvolvimento social. Ambos apontavam para a perspectiva de que o mundo futuro ficaria ainda melhor. Em 1998, Fernando Henrique acenava para um futuro de estabilidade econômica e geração de 
empregos. Em 2006, Lula reforçava ter criado condições para a aceleração do desenvolvimento econômico e social no mandato seguinte. As garantias apresentadas para legitimar seus discursos têm o mesmo fundamento: ativar no eleitorado o sentimento de escolha retrospectiva. A experiência do $1^{\circ}$ mandato e os indicadores positivos de gestão são os argumentos de persuasão (ver Quadros 1 e 2).

Quanto aos elementos explorados para a construção de imagem, Fernando Henrique, em 1998, salientou os valores honestidade/ integridade; firmeza/ força; competência e preparo; desempenho/ sucesso e dinamismo. Todos esses valores reforçam a imagem do bom gestor, da eficiência administrativa. Nota-se que a estratégia de Lula era a mesma, valores como competência, firmeza e performance também foram amplamente explorados no programa eleitoral do PT. Ao discursar, o candidato à reeleição em 2006 adotou posicionamento de mandatário, com a fala a partir do lugar do estadista, em defesa de seu governo. A linha argumentativa prevalecente durante toda a campanha foi centrada em revelar suas realizações em gestão. No entanto, o valor 'honestidade' não foi utilizado pelo candidatopresidente. Frente aos inúmeros escândalos de corrupção contra o PT, optou-se por não salientar essa dimensão (ver Quadros 3 e 4).

Já em relação aos elementos retóricos ${ }^{11}$, Fernando Henrique, em 1998, utilizou a estratégia de sedução em muitos momentos para, como diz Veiga (2001), criar apologias ao candidato. Os segmentos auxiliares foram utilizados para reforçar a imagem de liderança de FHC, além do uso da estratégia da modéstia como recurso de sedução, tal como mostra o trecho da fala do candidato em seu programa:

Fernando Henrique: Eu sei que pra você que está desempregado ou pra você que precisa colocar o filho na escola para trabalhar e não consegue vaga, é difícil acreditar que o Brasil mudou, melhorou, avançou. É para incluir você neste projeto que eu peço mais quatro anos (14 setembro 1998).

Os argumentos retóricos de ameaça também foram acionados, especialmente após o anúncio de crise econômica internacional. Os programas de FHC procuravam destaque com slogans como: "O pulso forte no momento de turbulência", ou com falas do locutor, "Em um momento de crise quem é o candidato mais preparado para conduzir o Brasil? Pense nisso" (15 de setembro 1998).

$\mathrm{Na}$ eleição presidencial de 2006 , os elementos retóricos mais evidentes na campanha de Lula foram relacionados a valores de identificação. Como

11 O conceito de elementos retóricos trata das dimensões argumentativas nas campanhas, dos dispositivos discursivos utilizados por candidatos para seduzir e persuadir os eleitores. 
mencionamos, essa estratégia foi acionada através do uso de recursos auxiliares: o uso de jingle e da vinheta de abertura. Em uma passagem do jingle, temos: "... são milhões de Lulas povoando esse Brasil..." e em outra: “... por um Brasil justo e independente, onde o presidente é povo e o povo é Presidente". A retórica da ameaça também foi acionada no fim do $1^{\circ}$ turno e reforçada no $2^{\circ}$ turno. Assim, no segmento auxiliar, o jingle em ritmo de samba sugeria ao eleitorado: "Não troque o certo pelo duvidoso. Eu quero Lula de novo". Embora Lula não utilizasse o espaço dos programas para argumentos de defesa às críticas de corrupção no partido, dialogou com o oponente no $2^{\circ}$ turno propondo inúmeros esquemas comparativos de resultados de gestão PT e PSDB. Por exemplo, salientou, em especial, a orientação do governo anterior em relação às privatizações. O texto do locutor em "off" do programa do dia 26/10, a seguir, releva a estratégia da ameaça (ver quadros 5 e 6):

LOC OFF - "O governo FHC privatizou a Vale do Rio Doce, Furnas. Será que eles vão respeitar a Petrobrás, o Banco do Brasil e a Caixa Econômica? Quero Lula de novo para não privatizar mais o que é do povo".

Das estratégias centrais desenvolvidas como mandatários, Fernando Henrique (1998) e Lula (2006) utilizaram a competência e o carisma como recursos diferenciadores, assim como buscaram argumentar através da ênfase em suas realizações e da associação à administração em curso. O uso de símbolos do cargo também apareceu recorrentemente em seus programas e Lula ainda lançou mão de imagens que reforçavam sua imagem frente a lideranças internacionais (ver Quadros 7 e 8).

No que diz respeito aos conteúdos das mensagens contidas no horário eleitoral, Fernando Henrique em 1998 não deu destaque ao discurso intimista, sua biografia administrativa ganhou muito mais relevância e os temas apresentados em seu programa eram significativamente de ordem administrativa: gravitando em torno do Plano Real. O candidato do PT à reeleição em 2006 também não privilegiou o discurso biográfico, optando por explorar os recursos de imagem. Quanto aos temas, a campanha de Lula ressaltou aqueles relacionados ao crescimento econômico e desenvolvimento social (ver Quadros 9 e 10 ).

Importante ressaltar que a tendência de minimizar a exposição do partido político foi forte tanto em 1998 quanto em 2006. O programa de Fernando Henrique fez algumas menções ao PSDB e ao grupo político que o apoiava, entretanto, havia centralidade na apologia ao candidato. Em 2006, a tendência de retirar o partido do cenário de visibilidade foi maior e o tom da campanha foi fortemente personalista: centrado na figura de Luiz Inácio Lula da Silva (ver Quadros 9 e 10). As referências simbólicas ao partido, que sempre estiveram 
presentes na representação midiática da corrida eleitoral, como a estrela do PT e o uso da cor vermelha, foram retirados de cena. Esse modo de encenação prevaleceu durante todo $\circ 1^{\circ}$ turno e já no $2^{\circ}$ turno, observou-se a utilização dos indícios do partido, mesmo que timidamente. Havia cenas com jovens utilizando bandanas do partido, bottons, faixas, mas utilizou-se, estranhamente, a estrela do PT representada com outras cores: branca, verde e, por vezes, no tradicional vermelho. Observa-se que a escolha do viés personalista esteve intimamente relacionada à fragilidade da imagem do Partido dos Trabalhadores na cena da política nacional em 2005 e 2006. Após as denúncias de escândalos de corrupção, esquemas ilícitos de remessas de dólares para o exterior, caixa dois de financiamento de campanha e, as CPI's que resultaram no afastamento das principais lideranças partidárias por envolvimento nos escândalos, a imagem do PT ficou fortemente fraturada. Desse modo, a escolha do enquadramento midiático centrado na figura do Presidente candidato minimizou a referência ao partido durante a corrida eleitoral.

Também é possível compreender a escolha da linguagem personalista da propaganda eleitoral do PT, com base na hipótese da fragilidade dos vínculos de identidade partidária do eleitorado brasileiro. Se fizermos uma análise comparativa sobre a preferência por partidos políticos veremos algumas alterações significativas de comportamento:

Quadro Comparado da Preferência Partidária em 2002 e 2006, Brasil ${ }^{12}$ :

\begin{tabular}{|c|c|c|c|c|c|c|c|}
\hline $\begin{array}{c}\text { Ano } \\
\text { eleitoral }\end{array}$ & $\begin{array}{c}\text { Sem } \\
\text { preferência } \\
\text { partidária }\end{array}$ & PT & PMDB & PSDB & PFL & $\begin{array}{c}\text { Outros } \\
\text { partidos }\end{array}$ & $\begin{array}{c}\text { Base } \\
\text { amostra }\end{array}$ \\
\hline 2006 & $65,4 \%$ & $14,7 \%$ & $7,6 \%$ & $4,6 \%$ & $1,7 \%$ & $5,8 \%$ & 5,811 \\
\hline 2002 & $59,4 \%$ & $22 \%$ & $6,6 \%$ & $3,8 \%$ & $2,6 \%$ & $5,2 \%$ & 8,068 \\
\hline
\end{tabular}

Segundo o quadro comparativo das preferências partidárias em 2002 e 2006, o que mais chama atenção é a redução do número de eleitores que preferem o PT, com uma queda de $7,3 \%$ em quatro anos. A tendência, no entanto, dos que não têm partido de preferência é ascendente, com uma evolução de seis pontos percentuais no período. Assim, nota-se que a estratégia de centrar o discurso da propaganda política eleitoral na figura do presidente - candidato esteve relacionada com a tendência de comportamento da população brasileira referente aos partidos políticos. Não há nenhuma referência no $1^{\circ}$ turno de uso de apoios políticos na campanha. A propaganda não revelava os aliados de Lula e com quem ele contaria para assessorá-lo no $2^{\circ}$ mandato. Já no $2^{\circ}$ turno, a estratégia mudou: os

12 Dados de preferência partidária no Brasil em 2006 e 2002. Disponível em: < www.Datafolha. folha.uol.com .br > Acesso em: 20 dez. 2006 
MACHADO, M. A retórica da reeleição: mapeando os discursos dos...

governadores eleitos ou em disputa apareceram como depoentes, declarando apoio ao candidato à reeleição.

Do ponto de vista do formato, o programa de Fernando Henrique em 1998 optou por um modelo com predomínio de elementos da linguagem do telejornalismo. O programa destacava o tom noticioso ao apresentar o conteúdo programático do candidato, os discursos de defesa a ataques da oposição eram apresentados em forma de vinheta com a locução do repórter em "off", segundo Veiga (2001). Em 2006, a estratégia do mandatário foi a mesma. Na medida em que Lula falava a partir da bancada de um cenário jornalístico, os demais oradores se posicionavam como locutores, os eleitores participavam da cena como depoentes, o programa ganhava em valorização da idoneidade discursiva. Nota-se que a escolha do gênero do telejornalismo prevaleceu e veio a atender certos princípios enunciativos. Em primeiro lugar, o princípio de familiaridade: o HGPE tem maior audiência no turno da noite e está em faixa de horário de programação próximo à grade dos telejornais em rede das principais emissoras de TV abertas no Brasil e adota, portanto, uma estratégia discursiva internalizada no modo de recepção do telespectador. Em segundo lugar, a credibilidade: o telejornal é fundamentalmente meio de informação. Certamente, no contexto da indústria cultural, a linguagem do entretenimento, o fait divers também pertence à lógica narrativa dos telejornais. No entanto, todos os programas do gênero valorizam sua dimensão noticiosa. Outro fenômeno recorrente do programa de Lula foi a utilização de notícias jornalísticas veiculadas em jornais impressos. Nesse caso, há que refletir sobre a presença desse outro agenciamento discursivo que entrava em cena para ratificar os argumentos sobre "a boa gestão de Lula no $1^{\circ}$ mandato". O jornal impresso simboliza a veracidade do discurso que está sendo tecido, como se vê no título da matéria de O Globo veiculado no HGPE do dia 12/09 em O Globo: "Renda sobe após 10 anos".

Lula não era o orador dominante da propaganda eleitoral gratuita. Nos seus programas no $1^{\circ}$ turno, os protagonistas eram três personagens que se apresentavam como locutores: uma mulher negra, um homem branco e um índio. A seleção dos personagens revelava indícios de uma estratégia já sinalizada na assinatura da marca BRASIL - um país de todos, inaugurada no início do governo Lula em 2002, e buscava revelar a identidade de um governo que se diz comprometido com a diversidade, com os múltiplos interesses, com a inclusão social. Tais personagens salientavam também os traços do imaginário popular sobre o Brasil: o país de miscigenação racial. O pano de fundo do cenário de onde os apresentadores falavam era sempre colorido, relevando essa dimensão do Brasil de múltiplas matizes. Já no $2^{\circ}$ turno, mais dois personagens foram adicionados: uma mulher loira e um jovem rapaz. Interessante ainda destacar que foi no segundo 
turno que o programa do PT deu ênfase a programas especificamente dirigidos às políticas públicas para mulheres e juventude (ver Quadro 12).

\section{Análise comparativa dos discursos dos candidatos oposicionistas em 1998 e 2006}

Em 1998, as campanhas oposicionistas estavam voltadas para avaliação do primeiro mandato de Fernando Henrique. Lula (PT) e Ciro Gomes (PPS) traduziam a imagem de mundo atual ruim. Para os partidos de oposição, a má administração do governo FHC gerou desemprego, recessão e vulnerabilidade na economia. Já em 2006, a tradução do mundo atual também foi negativa; entretanto, a crítica que se destaca é de ordem moral: a corrupção no governo desmoralizou a gestão de Lula. Geraldo Alckmin do PSDB questionou a eficiência administrativa do governo em curso, dizia que o Presidente arrecadava muito e investia mal, e destacava a ineficácia da política tributária e criticava os juros altos. Heloísa Helena do PSOL afirmou que o governo do PT deu continuidade à política econômica neoliberal do governo FHC e não priorizou as demandas sociais. Nos dois contextos, os candidatos de oposição apontavam uma perspectiva de mundo futuro ainda pior. Em 1998, o programa do PT destacava que o governo do PSDB iria lançar pacotes econômicos para assegurar o Plano Real frente à crise internacional, estimulando a recessão e o desemprego. Em 2006, Alckmin e Heloísa Helena salientavam a importância da estratégia da mudança, a ruptura com um modelo de governo que perdeu o controle frente à corrupção. Como garantia, todos os candidatos de oposição ofereciam sua trajetória na política. No caso de Lula em 1998, foi dada ênfase em sua biografia política e pessoal; Ciro Gomes enfatizou sua biografia administrativa. Em 2006, durante toda a trajetória da propaganda eleitoral, a ênfase biográfica do candidato do PSDB esteve centrada em indícios de sua vida pública. O discurso de Alckmin incluía valores como trabalho, competência, seriedade, mas sempre associados à sua experiência pública. Interessante salientar que seu registro biográfico como médico conferiu legitimidade a um conceito-chave adotado pela linha de comunicação com base no qual argumentou diversas vezes: "Meu compromisso é cuidar de gente". O discurso de Heloísa Helena não teve como tom a trajetória política, e seu programa esteve centrado em valores, como vemos no slogan "Coração valente, Heloísa Helena presidente" (ver quadros 1 e 2).

Em 1998, Lula construiu sua imagem enfatizando as características de honestidade, ternura/compaixão, competência; performance e indignação. Ciro Gomes concentrou-se em características que relevavam seu perfil administrativo, como competência e performance. Em 2006, nota-se que a estratégia dos oponentes também são similares. O posicionamento adotado por Alckmin na campanha foi de desafiante, muitas vezes tomado sutilmente, como no trecho do jingle "Já está na hora e no rosto desta gente, agora... é Geraldo presidente", ou em 
MACHADO, M. A retórica da reeleição: mapeando os discursos dos...

outra proposição: "Por um Brasil honesto e competente... Geraldo presidente". Heloísa Helena também se opôs a Lula com a defesa das características como honestidade, firmeza/força, através do tom de indignação (ver Quadro 3).

Quanto aos acionamentos retóricos, os oponentes centraram foco no discurso crítico. Em 1998, como diz Veiga (2001) ao discutir a estratégia do PT:

"O ataque a Fernando Henrique que já tinha centralidade no segmento de campanha do programa do PT ganhou ainda mais peso, restringindo o espaço para apresentação de propostas futuras e para apologia do candidato" (VEIGA, 2001, p.113).

Os programas de oposição em 1998 foram ganhando um ar panfletário, crítico, sem tempo de explanação dos conteúdos programáticos dos candidatos.

O mesmo ocorreu em 2006, mas o discurso crítico apareceu equilibrado com a ativação da satisfação retrospectiva no discurso do PSDB. Houve momentos em que o tom crítico da campanha de Geraldo Alckmin elevou-se, em especial, no período entre o desfecho do $1^{\circ}$ turno e início do $2^{\circ}$, quando a crise da compra do Dossiê dos Vedoin foi intensificada. A autoria da crítica é do apresentador e não de Geraldo Alckmin. Na tentativa de mapear um discurso de oposição, o candidato do PSDB marcou posição como o candidato da ética, da decência, do trabalho honesto. Embora sem explicitar, tentou fazer contraponto com a imagem maculada do PT com sucessivos escândalos de corrupção. Na campanha de Heloísa Helena, a estratégia como desafiante concentrou-se na contraposição ao PT e registrava sempre a posição de sua candidatura como a alternativa para ética e justiça social, uma alternativa aos governos corruptos. Procurou pontuar que PT e PSDB tinham o mesmo interesse em reforçar a política econômica neoliberal. No entanto, prevaleceu em sua abordagem a linguagem panfletária, sem um discurso com conteúdo programático.

O programa do PSDB em 2006 também equilibrou momentos de discurso retrospectivo, valorizando as realizações de Alckmin em suas gestões anteriores. A ponte para garantir legitimidade ao conteúdo programático para a Presidência da República esteve em sua frase de efeito, utilizada em diversos momentos da campanha:

LOC V: "Geraldo fez como governador vai fazer como Presidente". Ou nos momentos em que o próprio candidato diz: "Ofereço a você os meus 30 anos de vida pública".

Em termos de conteúdo programático, Alckmin argumentou de modo mais generalista. Muitas vezes, as propostas apareceram em lettering, sem muito tempo 
de explanação da viabilização dos projetos de reduzir os impostos, valorizar os pequenos e médios empresários, criar condições para melhorar o sistema público de saúde; investir em obras de infraestrutura, como hidrelétricas e estradas. Observa-se que, do ponto de vista dos programas de governo, PT e PSDB apresentaram propostas similares. Houve momentos em que Alckmin dizia que iria ampliar o Bolsa Família, sobrepondo-se à agenda do PT.

É possível sugerir que em 1998 e em 2006 o discurso da continuidade sobressaiu-se ao da mudança. Os discursos de mandatários transmitiram maior credibilidade e ofereceram maior segurança para o eleitorado. A perspectiva de que seus governos delineavam projetos em construção, e que para avançar com as reformas precisariam estar no poder por mais quatro anos, fez dos candidatos à reeleição Fernando Henrique Cardoso e Luiz Inácio Lula da Silva as melhores escolhas. Assim, ambos foram reconduzidos ao cargo por mais um mandato.

\section{Considerações finais}

Apesar das substantivas diferenças na conjuntura política, no agendamento da mídia, nas trajetórias políticas e vinculações partidárias dos candidatos à reeleição em 1998 e 2006, observamos focos de convergência nas estratégias utilizadas por Fernando Henrique (PSDB) e Lula (PT) para reafirmação da continuidade de seus governos. Como vimos, a tentativa de gerar uma sensação retrospectiva no eleitorado através da explanação dos melhores indicadores de seus governos revela os usos da gestão em curso em favor da candidatura. 0 discurso do PSDB em 1998 esteve centrado nas garantias de melhores condições de vida para a sociedade brasileira a partir do Plano Real, especialmente em ativar a sensação de como a vida da população melhorou com o suposto controle da inflação. O discurso do PT em 2006 traduziu-se pelas garantias de crescimento econômico (abertura de portos, Programa Luz para Todos, política de geração de empregos) associadas às mudanças na área social (com destaque para as políticas do Bolsa Família, PróJovem, Universidade para Todos). A tradução do mundo atual a partir de uma agenda de positividades foi também estratégia dominante nos dois casos. Como vimos, FHC em 1998 falou com entusiasmo que o Plano Real estava assegurado, mas que a garantia da continuidade dependia de sua permanência por mais quatro anos. Lula defendeu que o caminho escolhido em associar crescimento econômico à ampliação da ação social precisava ser garantido com a continuidade do governo do PT. O lugar de autoridade de que falou o candidato-Presidente acabou por conferir maior credibilidade ao mandatário, em detrimento das demais candidaturas. As imagens de estadista de FHC e Lula nos respectivos programas eleitorais reforçam a idealização de que quem está no poder deve ficar. Assim, a estratégia da ameaça é acionada para apontar que quem vislumbra o melhor mundo futuro é o candidato 
da situação. A ênfase nos temas de cunho administrativo e o foco para questões econômicas também se revelam como estratégias que favorecem os candidatos da situação, na medida em que alimentam no eleitorado a impressão de que suas políticas públicas serão mais eficientes do que as dos oponentes, que muitas vezes não têm elementos para sustentar uma sensação retrospectiva no eleitorado.

Diante desses indícios, torna-se urgente a discussão mais ampliada do processo de reeleição para cargos majoritários na sociedade brasileira e suas implicações para o futuro da democracia representativa.

\section{Referências Bibliográficas}

ALDÉ, A. A Construção da Política - Democracia, Cidadania e Meios de Comunicação de Massa. Rio de Janeiro: Editora FGV, 2004.

AZEVEDO, F. A. A agenda da mídia na campanha presidencial de 1998. [online] Disponível em: <www.unb.br/fac/comunicacaoepolitica>. Acesso em: 20 fev. 2007.

BOUDON, R. The Art of Self-Persuasion. Cambridge, UK: Polity Press, 1994.

CAMARGOS, M. B. Do bolso às urnas - A influência da economia na escolha entre Fernando Henrique e Lula nas eleições de 1998. Rio de Janeiro. Dissertação de mestrado em Ciência Política, - IUPERJ, 1999.

CAMPBELL, A.; CONVERSE, P. E.; MILLER, W. E. e STOKES, D. E. The American Voter. New York: John Wiley \& Sons, 1964.

DOWNS, A. An Economic Theory of Democracy. New York: Haroer Collins, 1957.

FIGUEIREDO, M. A Decisão do Voto. São Paulo: Editora Sumaré /ANPOCS, 1991.

"A Lei de Ferro da Competição Eleitoral: A Aritmética Eleitoral ou Eleições Casadas, Resultados Solteiros e o Dilema dos Partidos". Cadernos de Conjuntura, $n^{\circ} 50$, IUPERJ, Rio de Janeiro, julho de 1994. 
Mídia, Mercado de Informação e Opinião Pública. In: GUIMARÃES, C. e JUNIOR, C. (Orgs.). Informação e Democracia. Rio de Janeiro: Editora UERJ, 2000.

FIGUEIREDO, M., et al. Estratégias de Persuasão em Eleições Majoritárias. In: FIGUEIREDO, R. (Org.). Marketing Político e Persuasão Eleitoral. São Paulo: Fundação Konrad Adenauer, 2000.

FIORINA, M. Retrospective voting in American Nacional Election. New Haven: Yale University Press, 1981.

FEREJOHN, J. A. e KUKLINSKI, J. H. Information and Democratic Processes. Chicago: University of Illinois Press, 1990

GEERTZ, C. N. The theatre state in nineteenth century Bali. Princeton: Princeton University Press, 1980.

GOMES, W. Transformações da política na era da comunicação de massa. São Paulo: Ed. Paulus, 2004.

GROFMAN, B. Information, participation, and choice: an economic theory of democracy in perspective. Ann Arbor: University of Michigan Press, 1993.

HOLBROOK, T. M. Do Campaigns Matter? Thousan Oaks, London: Sage Publications, 1996.

LUPIA, A. e McCUBBINS, M. D. The Democratic Dilemma - Can Citizens Learn What They Need to Know? Cambridge: Cambridge University Press, 1999.

MIGUEL, L. F. Política e mídia no Brasil. Episódio da história recente. Brasília: Plano Editora, 2002

NOELLE-NEUMANN, E. "Pesquisa Eleitoral e Clima de Opinião". Opinião Pública, Ano I, vol. 1, $\mathrm{n}^{\circ} 2$, dezembro 1993. 
OLIVEIRA, L. A. A disputa política na televisão: uma análise das estratégias discursivas dos candidatos Fernando Henrique Cardoso e Luiz Inácio Lula da Silva no Horário Gratuito de Propaganda Eleitoral. Rio de Janeiro: Dissertação de mestrado em Ciência Política, IUPERJ, 2005.

POPKIN, S. L. The reasoning voter - communication and persuasion in presidential campaigns. Chicago: The University of Chicago Press, 1994.

POPKIN, S. L. et al. "Comment: Toward an Investment Theory of Voting Behavior: What Have You Done for Me Lately?". American Political Science Review, vol.70, n³, p.779-805, Sept. 1976.

RUBIM, A. Mídia e eleições de 1998. Editora Universitária UFPB, Facom/ UFBA, 1998.

TRAQUINA, N. "Paradigmas do agenda-setting". Jornalismo 2000 - Revista de Comunicação e Linguagem, $\mathrm{n}^{\circ} 27$, EDUSP, 2000.

VEIGA, L. F. Em busca de razões para o voto: o uso que o homem comum faz do horário eleitoral.Rio de Janeiro. Tese de Doutorado em Ciência Política, IUPERJ, 2001.

VENTURI, G. "Pesquisas Pré-eleitorais: Legitimidade, influência e contribuições à cidadania". Opinião Pública, vol. 3, n² 2, agosto de 2005.

YOUNG, J. T. et. al. "Influência da Mídia no Apoio a Candidatos à Presidência". Opinião Pública, vol. 2, $\mathrm{n}^{\circ} 1$, junho 1994. 


\section{Anexos}

\section{Quadro 1 - Estrutura dos Discursos da Situação e Oposição Campanha Presidência da República - 1998}

\begin{tabular}{|c|c|c|c|}
\hline Interpretação & Fernando Henrique & Lula & Ciro Gomes \\
\hline Mundo Atual & $\begin{array}{l}\text { Bom. } \\
\text { Controle da inflação. } \\
\text { Estabilidade } \\
\text { econômica. } \\
\text { Crise internacional } \\
\text { sob controle. } \\
\text { Real está } \\
\text { assegurado. }\end{array}$ & $\begin{array}{l}\text { Ruim. } \\
\text { Má gestão da política } \\
\text { tributária. Muitos impostos } \\
\text { e juros altos. Governo do } \\
\text { PT arrecada muito e } \\
\text { investe mal. A corrupção no } \\
\text { governo impede a } \\
\text { realização de políticas } \\
\text { públicas eficientes. }\end{array}$ & $\begin{array}{l}\text { Ruim } \\
\text { O Plano Real começou } \\
\text { bem, mas por uma } \\
\text { jogada errada do atual } \\
\text { governo trouxe recessão } \\
\text { e desemprego. A má } \\
\text { administração } \\
\text { desequilibrou as contas } \\
\text { públicas, endividando o } \\
\text { país, que, para pagar a } \\
\text { dívida, vem aumentando } \\
\text { os juros e quebrando } \\
\text { empresas e promovendo } \\
\text { o desemprego. }\end{array}$ \\
\hline Mundo Futuro & $\begin{array}{l}\text { Manutenção da } \\
\text { estabilidade } \\
\text { econômica. } \\
\text { Geração de } \\
\text { empregos. }\end{array}$ & $\begin{array}{l}\text { Para assegurar o Real } \\
\text { diante da ameaça da crise } \\
\text { internacional e pagar os } \\
\text { juros aos banqueiros e } \\
\text { especuladores, o governo } \\
\text { lança pacotes econômicos } \\
\text { que virão a promover a alta } \\
\text { dos juros, paralisando } \\
\text { ainda mais a economia } \\
\text { levando a um maior } \\
\text { desemprego. }\end{array}$ & $\begin{array}{l}\text { O candidato não } \\
\text { descreve um mundo } \\
\text { futuro. Descreve o } \\
\text { mundo atual e induz que } \\
\text { o eleitor pense no mundo } \\
\text { futuro, lançando a } \\
\text { pergunta: O que você } \\
\text { quer para o futuro? }\end{array}$ \\
\hline O que fazer & $\begin{array}{l}\text { Investir em geração } \\
\text { de empregos diretos } \\
\text { da administração } \\
\text { pública e incentivar } \\
\text { as pequenas, } \\
\text { médias e grandes } \\
\text { empresas. } \\
\text { Incentivos também } \\
\text { para o produtor } \\
\text { rural. }\end{array}$ & $\begin{array}{l}\text { Priorizar as demandas } \\
\text { sociais e econômicas da } \\
\text { população em detrimento } \\
\text { do compromisso com o } \\
\text { mercado financeiro } \\
\text { internacional. Oferecer } \\
\text { crédito com juros baixos } \\
\text { para promover o } \\
\text { aquecimento da economia } \\
\text { e garantir a geração de } \\
\text { empregos. }\end{array}$ & $\begin{array}{l}\text { Alterar as regras } \\
\text { econômicas da política } \\
\text { neoliberal das relações } \\
\text { internacionais em } \\
\text { prejuízo dos interesses } \\
\text { da população. Organizar } \\
\text { o Estado e apresentar as } \\
\text { diretrizes econômicas. }\end{array}$ \\
\hline Garantia & $\begin{array}{l}\text { A experiência do } \\
\text { primeiro mandato e } \\
\text { o sucesso na } \\
\text { estabilização da } \\
\text { moeda. }\end{array}$ & $\begin{array}{l}\text { A sua história de vida e sua } \\
\text { trajetória política. }\end{array}$ & $\begin{array}{l}\text { A sua capacidade e } \\
\text { experiência adquiridas } \\
\text { como ministro da } \\
\text { economia no governo } \\
\text { Itamar, como governador } \\
\text { do Ceará e como prefeito } \\
\text { de Fortaleza. }\end{array}$ \\
\hline
\end{tabular}

Fonte: reproduzido de Veiga (2001), p.121. 
MACHADO, M. A retórica da reeleição: mapeando os discursos dos...

\section{Quadro 2 - Estrutura dos Discursos a Situação e Oposição Campanha Presidência da República - 2006}

\begin{tabular}{|c|c|c|c|}
\hline Interpretação & Lula & Geraldo Alckimin & Heloisa Helena \\
\hline Mundo Atual & $\begin{array}{l}\text { Bom. } \\
\text { Bons indicadores de } \\
\text { desenvolvimento } \\
\text { econômico. } \\
\text { Bons indicadores de } \\
\text { desenvolvimento social. } \\
\text { Diferencial: associação do } \\
\text { crescimento econômico } \\
\text { com transferência de renda } \\
\text { para as classes populares. } \\
\text { Investimento em novas } \\
\text { tecnologias. }\end{array}$ & $\begin{array}{l}\text { Ruim. } \\
\text { Má gestão da política } \\
\text { tributária. Muitos } \\
\text { impostos e juros altos. } \\
\text { Governo do PT } \\
\text { arrecada muito e } \\
\text { investe mal. A } \\
\text { corrupção no governo } \\
\text { impede a realização de } \\
\text { políticas públicas } \\
\text { eficientes. }\end{array}$ & $\begin{array}{l}\text { Ruim } \\
\text { A corrupção no governo } \\
\text { desmoralizou a gestão de } \\
\text { Lula. } \\
\text { Política econômica } \\
\text { adotada a partir de } \\
\text { modelo neoliberal. } \\
\text { Governo não prioriza as } \\
\text { demandas sociais e tem } \\
\text { foco no compromisso } \\
\text { com o mercado financeiro } \\
\text { internacional. }\end{array}$ \\
\hline $\begin{array}{l}\text { Mundo } \\
\text { Futuro }\end{array}$ & $\begin{array}{l}\text { Programa de aceleração do } \\
\text { crescimento ( PAC). } \\
\text { Ampliação de reformas: } \\
\text { foco na área educacional e } \\
\text { políticas de geração de } \\
\text { emprego. }\end{array}$ & $\begin{array}{l}\text { A corrupção vai } \\
\text { continuar e as políticas } \\
\text { públicas sofrerão as } \\
\text { consequências. O } \\
\text { governo continuará } \\
\text { arrecadando muito e } \\
\text { investindo sem } \\
\text { planejamento, } \\
\text { estimulando o } \\
\text { crescimento } \\
\text { desordenado. }\end{array}$ & $\begin{array}{l}\text { O foco da política } \\
\text { econômica será o de } \\
\text { privilegiar os } \\
\text { especuladores e o capital } \\
\text { financeiro internacional. } \\
\text { Sem foco para o social. } \\
\text { A corrupção continuará e } \\
\text { impedirá o } \\
\text { desenvolvimento de } \\
\text { políticas públicas } \\
\text { essenciais. }\end{array}$ \\
\hline O que fazer & $\begin{array}{l}\text { Reduzir ainda mais a } \\
\text { desigualdade social no } \\
\text { Brasil, através de } \\
\text { programas sociais que } \\
\text { integrem transferência de } \\
\text { renda, compromisso com a } \\
\text { qualificação e geração de } \\
\text { novas frentes de trabalho. } \\
\text { Entre as reformas, eleger a } \\
\text { educação como prioridade } \\
\text { máxima. }\end{array}$ & $\begin{array}{l}\text { Ampla reforma } \\
\text { tributária para redução } \\
\text { de impostos. } \\
\text { Campanha de } \\
\text { moralização na } \\
\text { política, punindo os } \\
\text { envolvidos em } \\
\text { escândalos de } \\
\text { corrupção. Programar } \\
\text { um Plano Nacional de } \\
\text { Desenvolvimento. }\end{array}$ & $\begin{array}{l}\text { O programa não } \\
\text { desenvolve bem o que } \\
\text { fazer. Está mais centrado } \\
\text { em criticar o governo do } \\
\text { PT. Quando o discurso é } \\
\text { propositivo, o foco é em } \\
\text { investimentos na área } \\
\text { social. }\end{array}$ \\
\hline Garantia & $\begin{array}{l}\text { A sua história de vida e } \\
\text { trajetória política, a } \\
\text { experiência do } 1^{\circ} \text { mandato } \\
\text { e a os bons indicadores da } \\
\text { área econômica e social. }\end{array}$ & $\begin{array}{l}\text { Sua gestão no governo } \\
\text { de São Paulo; sua } \\
\text { capacidade } \\
\text { administrativa. }\end{array}$ & $\begin{array}{l}\text { Sua carreira no } \\
\text { legislativo. A imagem de } \\
\text { uma trajetória honesta, } \\
\text { transparente. }\end{array}$ \\
\hline
\end{tabular}

Fonte: elaboração da autora, baseado em Veiga (2001). 
Quadro 3

Construção da imagem: Características pessoais enfatizadas na Campanha para Presidência da República - 1998

\begin{tabular}{|l|c|c|c|}
\hline Características pessoais & Fernando Henrique & Lula & Ciro Gomes \\
\hline Honestidade/ integridade & 20 & 20 & 9 \\
\hline Firmeza/ força & 20 & 5 & 15 \\
\hline Ternura/ compaixão & 5 & 20 & 5 \\
\hline Competência/ preparo & 20 & 20 & 17 \\
\hline Performance/ sucesso & 20 & 20 & 17 \\
\hline Agressividade & $\ldots$ & 12 & 2 \\
\hline Dinamismo & 20 & 5 & 5 \\
\hline Indignação & $\ldots$ & 20 & 13 \\
\hline Juventude & $\ldots$ & $\cdots$ & $\cdots$ \\
\hline
\end{tabular}

Fonte: reproduzido de Veiga (2001), p.122.

\section{Quadro 4}

Construção da imagem: Características pessoais enfatizadas na Campanha para Presidência da República - 2006

\begin{tabular}{|l|c|c|c|}
\hline Características pessoais & Lula & Geraldo Alckmin & Heloísa Helena \\
\hline Honestidade/ integridade & 5 & 36 & 13 \\
\hline Firmeza/força & 36 & 26 & 13 \\
\hline Ternura/ compaixão & 26 & 17 & 9 \\
\hline Competência/ preparo & 29 & 28 & 1 \\
\hline Performance/ sucesso & 28 & 5 & $\cdots$ \\
\hline Agressividade & $\cdots$ & 3 & 4 \\
\hline Dinamismo & 13 & 26 & $\cdots$ \\
\hline Indignação & 5 & 5 & 10 \\
\hline Juventude & $\cdots-$ & $\cdots$ & $\cdots$ \\
\hline
\end{tabular}

Fonte: elaboração da autora, baseado em Veiga (2001). 
Quadro 5

Construção do discurso

Campanha para Presidência da República - 1998

\begin{tabular}{|l|c|c|c|}
\hline \multicolumn{1}{|c|}{ Retórica } & FHC & Lula & Ciro Gomes \\
\hline Sedução & 20 & 7 & 7 \\
\hline Proposição & 20 & 8 & 10 \\
\hline Crítica & 1 & 19 & 16 \\
\hline Valores & 3 & 20 & 8 \\
\hline Ameaça & 20 & 12 & 5 \\
\hline Prestação de contas & $\cdots$ & $\ldots \cdot$ & $\cdots$ \\
\hline Linguagem & & & \\
\hline Didática & $\ldots . \cdot$ & $\ldots \cdot$ & 1 \\
\hline Informativa & 20 & 13 & 6 \\
\hline Panfletária & 20 & 19 & 18 \\
\hline
\end{tabular}

Fonte: reproduzido de Veiga (2001), p.125.

Quadro 6

Construção do discurso

Campanha para Presidência da República - 2006

\begin{tabular}{|l|c|c|c|}
\hline \multicolumn{1}{|c|}{ Retórica } & Lula & Geraldo Alckmin & Heloísa Helena \\
\hline Sedução & 15 & 2 & 10 \\
\hline Proposição & 16 & 17 & 3 \\
\hline Crítica & 6 & 30 & 14 \\
\hline Valores & 30 & 36 & 7 \\
\hline Ameaça & 25 & 11 & $\ldots$ \\
\hline Prestação de contas & 24 & 35 & $\ldots$ \\
\hline \multicolumn{1}{|c|}{ Linguagem } & & & $\ldots$ \\
\hline Didática & $\ldots \ldots$ & $\ldots \ldots$ & 1 \\
\hline Informativa & 24 & 28 & 16 \\
\hline Panfletária & 16 & 15 & \\
\hline
\end{tabular}

Fonte: elaboração da autora, baseado em Veiga (2001). 


\section{Quadro 7}

Mandatário e Desafiantes: Estratégias usadas para a disputa do cargo Campanha Presidência da República - 1998

\begin{tabular}{|c|c|c|c|}
\hline Estratégias & Fernando Henrique & Lula & $\begin{array}{l}\text { Ciro } \\
\text { Gomes }\end{array}$ \\
\hline \multicolumn{4}{|l|}{ Estratégia de Mandatário } \\
\hline Carisma e cargo & 20 & $\cdots$ & $\cdots$ \\
\hline Competência e cargo & 20 & $\cdots$ & $\cdots$ \\
\hline Símbolos do cargo & 18 & $\cdots$ & $\cdots$ \\
\hline Postura acima da briga & 16 & $\cdots$ & $\cdots$ \\
\hline Ênfase em realizações & 20 & 3 & $\cdots$ \\
\hline $\begin{array}{l}\text { Associação com a administração em } \\
\text { curso }\end{array}$ & 20 & $\cdots$ & $\cdots$ \\
\hline $\begin{array}{l}\text { Encontro com lideranças nacionais e } \\
\text { internacionais }\end{array}$ & 10 & 4 & $\cdots$ \\
\hline Endosso de lideranças & 1 & 4 & $\cdots$ \\
\hline Endosso de líderes partidários & 2 & 5 & $\cdots$ \\
\hline Uso de patrono do candidato & $\cdots$ & $\cdots \cdot$ & $\cdots$ \\
\hline \multicolumn{4}{|l|}{ Estratégia do desafiante } \\
\hline Apelo à mudança & $\cdots$ & 20 & 20 \\
\hline Ofensiva quanto a tema & 13 & 18 & 10 \\
\hline Ênfase no otimismo futuro & 20 & 4 & 5 \\
\hline Ataques a administração em curso & $\cdots$ & 20 & 17 \\
\hline Ataque ao adversário & 1 & 19 & 17 \\
\hline Comparação & $\cdots$ & $\cdots$ & 5 \\
\hline
\end{tabular}

Fonte: reproduzido de Veiga (2001), p.123. 


\section{Quadro 8 \\ Mandatário e Desafiantes: Estratégias usadas para a disputa do cargo Campanha Presidência da República - 2006}

\begin{tabular}{|c|c|c|c|}
\hline Estratégias & Lula & $\begin{array}{l}\text { Geraldo } \\
\text { Alckmin }\end{array}$ & Heloisa Helena \\
\hline \multicolumn{4}{|l|}{ Estratégia de Mandatário } \\
\hline Carisma e cargo & 21 & .... & $\ldots$ \\
\hline Competência e cargo & 23 & 24 & $\ldots$ \\
\hline Símbolos do cargo & 24 & 21 & $\cdots$ \\
\hline Postura acima da briga & 16 & $\cdots \cdot$ & $\cdots$ \\
\hline Ênfase em realizações & 22 & 36 & $\cdots$ \\
\hline Associação com a administração em curso & 22 & 36 & $\cdots$ \\
\hline $\begin{array}{l}\text { Encontro com lideranças nacionais e } \\
\text { internacionais }\end{array}$ & 6 & 4 & $\cdots$ \\
\hline Endosso de lideranças & $\cdots$ & 9 & $\ldots$ \\
\hline Endosso de líderes partidários & 6 & 13 & $\cdots$ \\
\hline Uso de patrono do candidato & $\cdots \cdot$ & $\cdots \cdot$ & $\cdots$ \\
\hline \multicolumn{4}{|l|}{ Estratégia do desafiante } \\
\hline Apelo à mudança & $\cdots$ & 32 & 16 \\
\hline Ofensiva quanto a tema & & 14 & 10 \\
\hline Ênfase no otimismo futuro & 9 & $\ldots$ & \\
\hline Ataques a administração em curso & $\cdots$ & 25 & 13 \\
\hline Ataque ao adversário & 1 & 23 & 9 \\
\hline Comparação & 23 & 24 & 1 \\
\hline
\end{tabular}

Fonte: elaboração da autora, com base em Veiga (2001). 


\section{Quadro 9}

Conteúdo das mensagens contidas no Horário Eleitoral - 1998

\begin{tabular}{|l|c|c|c|}
\hline Candidato & FHC & Lula & Ciro \\
\hline Biografia administrativa & 17 & $\ldots$ & 13 \\
\hline Biografia política & 7 & 7 & 3 \\
\hline Imagem & 20 & 7 & 14 \\
\hline Posição na competição & 6 & 20 & 20 \\
\hline Partido & FHC & Lula & Ciro Gomes \\
\hline Ênfase administrativa & 4 & 4 & $\ldots$ \\
\hline Ênfase Política & 2 & 6 & 2 \\
\hline Ausência de referência & 14 & 10 & 18 \\
\hline Grupo político & FHC & Lula & Ciro Gomes \\
\hline Ênfase administrativa & 4 & 4 & $\ldots$ \\
\hline Ênfase política & 2 & 6 & 2 \\
\hline Ausência de referência & 14 & 10 & 18 \\
\hline Temas & FHC & Lula & Ciro Gomes \\
\hline Administrativos & 20 & $\cdots$ & 10 \\
\hline Políticos & 4 & 7 & 3 \\
\hline Sociais & 7 & 10 & 1 \\
\hline Econômicos & 9 & 13 & 10 \\
\hline Cardápio & 4 & $\ldots$ & $\ldots$ \\
\hline Ensinar a votar & 5 & 2 & 2 \\
\hline
\end{tabular}

Fonte: VEIGA (2001) 
Quadro 10

Conteúdo das mensagens contidas no Horário Eleitoral - 2006

\begin{tabular}{|l|c|c|c|}
\hline Candidato & Lula & Alckimin & Heloisa Helena \\
\hline Biografia administrativa & 5 & 24 & $\ldots$ \\
\hline Biografia política & 6 & 23 & 1 \\
\hline Imagem & 36 & 21 & 5 \\
\hline Posição na competição & 6 & $\ldots$ & 1 \\
\hline Partido & Lula & Geraldo Alckmin & Heloísa Helena \\
\hline Ênfase administrativa & $\ldots$ & $\ldots$ & $\ldots$ \\
\hline Ênfase Política & $\ldots$ & $\ldots$ & 6 \\
\hline Ausência de referência & 36 & 36 & 9 \\
\hline Grupo político & Lula & Geraldo Alckmin & Heloísa Helena \\
\hline Ênfase administrativa & 2 & 8 & $\ldots$ \\
\hline Ênfase política & 3 & 11 & 5 \\
\hline Ausência de referência & 28 & 9 & 8 \\
\hline Temas & Lula & Geraldo Alckmin & Heloísa Helena \\
\hline Administrativos & 36 & 21 & $\ldots$ \\
\hline Políticos & 8 & $\ldots$ & 2 \\
\hline Sociais & 21 & 12 & 8 \\
\hline Econômicos & 20 & 6 & 2 \\
\hline Cardápio & 5 & 24 & $\ldots$ \\
\hline Ensinar a votar & 8 & 3 & 3 \\
\hline Fone elaraço autora, com & ba & & \\
\hline
\end{tabular}

Fonte: elaboração da autora, com base em Veiga (2001).

Mônica Machado·monicmachado@terra.com.br

Recebido para publicação em julho de 2008.

Aprovado para publicação em novembro de 2008. 